\title{
Library Operations Research and Systems Engineering Studies
}

\author{
By MOLETE MORELOCK AND F. F. LEIMKUHLER
}

ONE of the difficulties in getting a systems engineering study started in the library is the difference in terminology, traditions, and techniques in the two fields. Many librarians know little about operations research, and many operations research people know little about the library. In the preliminary stages of a study started at Purdue University in February 1963 Professor F. F. Leimkuhler, of the school of industrial engineering, conducted a weekly seminar with a committee of the professional staff of the libraries and some graduate students interested in operations research. Techniques and methods of operations research were reviewed; the organization, policies, and procedures of the Purdue University libraries were discussed; and a framework was established for future research projects.

Most of the studies which were later carried out were conducted as project assignments in Professor Leimkuhler's class in operations research. These projects can be considered as pilot studies aimed chiefly at developing and refining methodology. During the summer and fall of 1963 no library-operations research seminars were held. The operations research students worked closely with the library staff on projects, and reports were written. During the spring of 1964 the weekly seminar with the library staff was resumed, and each of the project reports was reviewed by the group.

Two students ${ }^{1}$ attempted to determine how to store periodical volumes by considering the growth of the collection and the accessibility of different storage areas.

\footnotetext{
${ }^{1} \mathrm{~T}$. Rehg and G. Huber, "Optimum Distribution for Bound Serials in Purdue's General Library."
}

Miss Morelock is Coordinator of Regional Campus Libraries and $\mathrm{Mr}$. Leimkuhler is Associate Professor of Industrial Engineering, Purdue University.

Mathematical models were developed to forecast growth and to predict the transfer of volumes to the stacks as growth necessitates. Recommendations for future study were made.

On a campus where there are numerous departmental libraries, duplication is inevitable. An evaluation was made of the number, location, cost, and use of all statistics books in the Purdue library system. ${ }^{2}$ The object was to determine whether duplication was adequate, inadequate, or excessive. A mathematical model for predicting availability on a departmental and system level was developed, evaluated on an IBM 7090 computer, and used to measure the cost of duplication in order to attain a given level of availability for various loan policies.

The operation of the reserve book room was studied. ${ }^{3}$ Checkout patterns over the previous two years were used to develop a model for determining work force requirements.

In another study, a one-month survey was made of the demand pattern for the circulation of bound periodicals with some experimental changes in policy. ${ }^{4}$ The model was used to evaluate performance under various alternatives.

An attempt was made to explain the

${ }^{2}$ E. T. O'Neill, F. Talcott, and H. Speer, "Analysis of Book Duplication."

3 J. Farlander and D. Gibson, "Operation of the Reserve Book Room."

${ }^{4}$ V. P. Bhende and K. N. Patel, "Evaluation of the Policy of Circulating Periodicals." 
changing patterns of use in a popular book collection and reading room at Purdue called The Bookstall. ${ }^{5}$ An opinion and use survey was used as a basis to define a "satisfied" student. A queuing-type model was developed to aid in the design and arrangement of table facilities. Many interesting facts about the use patterns in The Bookstall were uncovered.

An inventory of books in the industrial administration library was used to construct a "decision-tree" for replacement and to estimate the budget requirements for replacing lost books. ${ }^{6}$ Differences in loss patterns for different classes of books and users were detected.

There is a centralized inventory of supplies for all parts of the Purdue libraries which results in a fairly complex system of ordering, holding, and distributing supply items. Two different groups studied this supply system. ${ }^{7}$ Demand and cost parameters were evaluated and used in a mathematical model which established the optimal order frequency and quantity for twenty-one major items. The model indicated that it may be possible adequately to meet demands and still tie up less funds in stock, which would permit greater budget flexibility. A different model was developed and evaluated which minimized inventory costs subject to spatial restraints. A detailed analysis of the cost of ordering items and the cost of stocks was made in support of the program.

One doctoral candidate in industrial engineering has based his research on a study of the libraries. Cox did his work on Optimum Storage of Library Materials. ${ }^{8}$ The primary purpose of this research

\footnotetext{
${ }^{5}$ M. N. Tata, P. K. Murgai, and D. J. Sheth, "Study of The Bookstall."

C. A. Fuller and J. E. Jackson, "Book Loss and Replacement in the Industrial Administration Library."

" B. Kobu, J. M. Myers, and H. W. Uribe, "An Inventory Model for the Purdue Library Supply System"; C. Neve and G. Bozoke, "An Inventory Model Applied to Library Supply Stock."

8 Julius Grady Cox, "Optimum Storage of Library Material" (PhD, dissertation, Purdue University, 1964) ; F. F. Leimkuhler and J. G. Cox, "Compact Book Storage in Libraries," Operations Research, XII (May-June 1964), 419-27.
}

was to develop, discuss, and demonstrate compact storage models. Since much space is lost because shelves are arranged to take care of the largest books on the shelf, the idea of storing books by size was explored. The values of shelf height were chosen such that the storage space was minimized. Two-dimensional and three-dimensional models were developed. In addition to the sample data from Purdue University, a large sample of data from Auburn University was collected. An interesting practical result of all the examples for all models was the small number of shelf heights (from three to five) required to be near an optimal solution.

$\mathrm{O}^{\prime} \mathrm{Neill}^{9}$ (who is a candidate for a master's degree) is now exploring the applicability of statistical sampling techniques for the estimation of significant characteristics of the library collections and the use of these materials. He has already made one report to the library group in which he described a very promising sampling technique he devised with the advice of the director of the statistical laboratory. ${ }^{10} \mathrm{~A}$ seven-digit number was chosen to represent each book in the collection (the classification number did not lend itself to statistical sampling). Each digit represented a characteristic of the location. A computer was used to generate eight-digit random numbers from a rectangular distribution. It truncated the numbers to seven digits and checked to see if they met all necessary requirements and sorted the numbers so that samples could be taken in an orderly manner. The location numbers selected were punched on IBM mark sense cards. Any information necessary can be mark sensed on these cards. This study will be continued in the

\footnotetext{
9 E. T. O'Neill, "Stack Composition Sampling Plan."

10 Other studies thus far completed, include: D. Edelman and G. Jouris, "Statistical Sampling of the Library Stacks"; H. T. Feng, "A Study of the Efficiency of the Industrial Engineering Library" A. K. Jain, M. Sadhasivam, and S. B. S. Sharma, "Book Utilization and Budget Allotments in the Industrial Administration Library"; C. B. MeCarthy, "Service Times Required for Book Purchases" F. Reinhardt, "Return of Overnight Books."
} 
fall. The technique appears to have interesting possibilities.

Looking forward to the fall semester 1964, several students in industrial engineering have indicated an interest in doing research in the library. The interde- partmental seminars together with the close cooperation between the members of the library staff and research teams is stimulating to both groups. A very favorable climate for continued research has been developed.

\title{
More ALA Awards, Citations, Scholarships, 1965
}

\begin{abstract}
Nominations are invited for the following awards, in addition to those listed on page 482 .

The Margaret Mann Citation is awarded by the Cataloging and Classification section of Resources and Technical Services Division of ALA, to a cataloger or classifier for outstanding professional achievement. Deadline for nominations is January 1. Any librarian or ALA member may send nominations to Katharine L. Ball, chairman, Margaret Mann Citation Committee, University of Toronto Library School, Toronto, Ont., Canada.

The Eunice Rockwell Oberly Memorial Award, consisting of a citation and the income of the Oberly Memorial Fund, is made to an American citizen who compiles the best bibliography in the field of agriculture or the related sciences in a two-year period. Nominations should be made to Francis P. Allen, University of Rhode Island, Kingston, chairman of the award committee, no later than March 15.

The Beta Phi Mu Award consists of $\$ 50$ and a citation; it is made to an individual for distinguished service to education for librarianship. The donor is Beta $\mathrm{Phi} \mathrm{Mu}$, international library science honor fraternity. Deadline for nominations is April 1. Send nominations to Robert L. Gitler, chairman, Beta Phi Mu Award Committee, George Peabody Library School, Nashville, Tenn.

The Library Binding Institute Scholarship is an annual $\$ 1,000$ scholarship given to a resident of the United States without regard to race, color, creed or geographic origin. It continues the scholarship program carried on for several years by its donor, the Library Binding Institute, and is administered by the Library Education Division of ALA. Information and application forms are available from the chairman of the committee, Robert E. Lee, Kansas State College Library, Emporia. Deadline for applications is April 1.
\end{abstract}

